\title{
ST. EPHREM IN THE EYES OF LATER SYRIAC LITURGICAL TRADITION
}

\author{
SEBASTIAN BROCK \\ UNIVERSITY OF OXFORD \\ ORIENTAL INSTITUTE
}

\section{INTRODUCTION}

The cover of Kathleen McVey's excellent collection of translations of St. Ephrem's hymns, in the Classics of Western Spirituality series, reproduces a modern icon of St. Ephrem, portraying him in monastic habit. Professor McVey was extremely aggravated when she learnt of the publisher's intention, but was unable to persuade them to change their plans. The reason for her annoyance lay in her knowledge that this was a totally misleading and anachronistic way of portraying the saint, whose true milieu belonged to the indigenous Syrian tradition of the consecrated life, prior to the arrival in Syria and Mesopotamia of the Egyptian monastic tradition which later dominated the scene. ${ }^{1}$ This anachronistic iconography of St. Ephrem goes back a long way, though it so happens that the earliest surviving icon portraying the saint, from St. Catherine's Monastery Sinai, portrays the saint in a rather more appropriate way. ${ }^{2}$ As we shall see, the later literary tradition concerning St. Ephrem also distorts the true image of the saint in a

${ }^{1}$ For this, see (e.g.) my The Luminous Eye: The Spiritual World Vision of St. Ephrem (Kalamazoo, 1992).

2 Illustrated in K.A. Manafis (ed.), Sinai: Treasures of the Monastery of Saint Catherine (Athens, 1990) 145. 
variety of different ways. In the present paper I shall confine myself to two aspects: first I shall briefly sketch out the growth of the biographical tradition as it gradually takes on purely legendary accretions; and secondly, since the liturgical tradition often acts as a good sounding board, I shall take a preliminary look at what this has to offer on St. Ephrem, in the course of the various commemorations that are made of him during the year.

\section{THE GROWTH OF THE BIOGRAPHICAL TRADITION} (see Table in Appendix I)

Here the obvious starting point is the document entitled the "History of the holy Mar Ephrem the Teacher," which comes down to us in several different recensions. ${ }^{3}$ I shall refer to it simply as the "Life."

3 There are two published forms of the Life: one, based on Vatican syr.117, was edited by P. Benedictus and J.E. Assemani, Sancti Patris Nostri Ephraem Syri Opera Omnia, III (Rome, 1743) xxii-lxiii [= V] (considerable extracts had appeared earlier in J.S. Assemani's Bibliotheca Orientalis, I (Rome, 1719) 26-55); and the second, based on Paris syr. 235, in T. Lamy, Sancti Ephraem Syri Hymni et Sermones, II (Malines, 1886) 3-89 [= P] (this was reprinted by P. Bedjan in Acta Martyrum et Sanctorum, III (Paris/Leipzig, 1892) 621-65). A comparative edition of P, V and British Library Or. 9384 [= L], accompanied by English translation and study, is available in J. Amar's Ph.D. dissertation, The Syriac Vita Tradition of Ephrem the Syrian (Catholic University of America, Washington DC, 1988). Other manuscripts containing the Life are Damascus, Syr. Orth. Patriarchate 12/17 (no. 62), Sinai (New Finds), Sparagmata Syriaka 53, British Library Or.4404. (An edition of the Life, using all the manuscripts, is in preparation by J.Amar; for the contents, see Appendix II). There are also Armenian and Georgian versions, the former (made in 1101) was edited by L. Petrossian and B. Outtier (CSCO 473-74, Arm. 14-15; 1981-5), and the latter by G. Garitte (CSCO 171-72, Iber. 5-6; 1957); both of these are closer to $\mathrm{P}$ than to $\mathrm{V}$. An Arabic translation remains unpublished; the oldest manuscripts belong to the 10th century (Sinai ar. 457, 520). 
Thanks to the work of Arthur Vööbus, ${ }^{4}$ Bernard Outtier, ${ }^{5}$ Sidney Griffith ${ }^{6}$ and Joseph Amar, ${ }^{7}$ the true character of this Life of Ephrem has become clear. Vööbus, for example, pointed out that the description of the river Daisan flowing round, and not through Edessa, indicated that the Life must belong to a time later than the flood of 525, after which the river's course was diverted. ${ }^{8}$ In the volume of Parole de l'Orient commemorating the 16th centenary of Ephrem's death, Outtier gave a masterly sketch of the main extant sources upon which the compiler of the Life drew. Building upon this, Griffith and Amar have shown how the Life, which is heavily dependent on Greek sources, has given rise to a portrait of an "Ephrem byzantinus," who is very different from the authentic "Ephrem syrus," author of the madräshe and other genuine writings. Basically, what the Life (along with other similar sources) has done is to "update" the portrait of the saint to meet sixth-century expectations. This has affected the picture of Ephrem in three ways in particular: firstly, instead of the deacon and (probably) ibidāya, or single-minded celibate follower of Christ the

${ }^{4}$ A. Vööbus, Literary Critical and Historical Studies in Ephrem the Syrian (Papers of the Estonian Theological Society in Exile 10; Stockholm, 1958) 22-32; and his History of Asceticism in the Syrian Orient, II (CSCO 197, Subs. 17; 1960) 77-80.

5 B. Outtier, "S.Ephrem d'après ses biographies et ses oeuvres," Parole de l'Orient 4 (1973): 11-33.

6 S. Griffith, "Images of Ephrem: the Syrian Holy Man and his Church," Traditio 45 (1989-90): 7-33.

${ }^{7} \mathrm{~J}$. Amar, "Byzantine ascetic monachism and Greek bias in the Vita tradition of Ephrem the Syrian," Orientalia Christiana Periodica 58 (1992): 123-56.

8 Vööbus, Literary Critical and Historical Studies, 29; cp. Procopius, Buildings II. vii.2-9. (For problems concerning the alteration of the river's course see A.N. Palmer, "King Abgar of Edessa, Eusebius and Constantine," in H. Bakker (ed.), The Sacred Centre as a Focus of Political Interest (Groningen, 1992) 3-29.

9 Griffith's terms, "Ephrem syrus" and "Ephrem byzantinus" might be better replaced (for the present purpose) by "authentic" and "anachronistic" Ephrem, since the latter portrait, "Ephrem Byzantinus," is by no means confined to the Greek world, even though many of the features are first attested there. 
Ibidāya (Only-Begotten), ${ }^{10}$ someone who worked primarily as a teacher (malpāna) in the midst of the urban Christian community of, first Nisibis and then Edessa, the Life portrays him as an ascetic monk and hermit, living for the most part in his cell on the mountains outside Edessa (the sort of figure depicted on the cover of Kathleen McVey's book). Secondly, this provincial from the eastern provinces of the Empire, who lacked a Greek-style education and had no direct contact with other great names of the fourth century (apart from with his local bishop, St. Jacob of Nisibis), has become, not only a rhetor to rival the Greeks, but also an international traveller, visiting St. Basil in Cappadocia, and St. Bishoi in Egypt, thus linking him with the wider Christian world. And thirdly (and perhaps the most regrettable of all), the man who wrote specifically for women's choirs, and whose portrayal of biblical women is quite exceptionally sympathetic, ${ }^{11}$ has been transformed into an unsmiling misogynist.

Since the details of the process by which this transformation happened have been well traced out by the scholars mentioned above, it is only necessary here to indicate some of the main features, concentrating primarily on those which will prove relevant when we come to the liturgical texts. One of our earliest biographical sources is Palladius, who devoted ch. 40 of his Lausiac History (c. 420) to Ephrem, and he happens to preserve what seems to be a genuine historical detail about Ephrem's organisation of famine relief for the poor of Edessa right at the end of his life; at the same time, however, he describes Ephrem as someone who otherwise lived in a cell, and who "was held worthy of natural knowledge, and subsequently of the divine, and of perfect beatitude" - in other words, someone who had successfully moved through the three Evagrian stages of the spiritual life. ${ }^{12}$ Some twenty or so years later the Church historian Sozomen ${ }^{13}$ describes Ephrem as someone who had "devoted his life to monastic

${ }^{10}$ See S.H. Griffith, “'Singles' and 'Sons of the Covenant.' Reflections on Syriac ascetic terminology," in E. Carr and others (eds.), Eulogema. Studies in Honor of R.Taft, S.J. (Studia Anselmiana 110; 1993) 141-60.

${ }^{11}$ See my The Luminous Eye, 168-72.

12 Palladius, Lausiac History, ch. 40.

13 Sozomen, Ecclesiastical History, III.16 (cp. also VI.34). Most of the passage is translated in my St. Ephrem the Syrian: Hymns on Paradise (New York, 1990) 15-9. 
philosophy;" moreover, "contrary to all expectation" his oratorical skills surpassed those of even "the most approved writers of Greece," and won the admiration of St. Basil, "the most eloquent man of his age." Sozomen further informs his readers that Bardaisan's son Harmonios, being "the first to subdue his native tongue to metres and musical laws" introduced some of his father's heretical teachings into his poems, and it was in order to counter the influence of these that Ephrem "applied himself to the understanding of the metres of Harmonios, and composed similar poems in accordance with the doctrines of the Church."14 Sozomen provides us with the first hint of Ephrem the misogynist, stating that "he refrained from the very sight of women." Sozomen's other information, such as the episode of his feigned madness to avoid consecration as a bishop, need not detain us. Theodoret, writing in the middle of the fifth century, is the first to hint at a role played by Ephrem, alongside his bishop Jacob, in a siege of Nisibis by Shapur II. ${ }^{15}$

Syriac translations of these Greek works were probably made in the course of the late fifth and early sixth century; that of Palladius' Lausiac History alone survives complete, and in this the Syriac translator has sandwiched Palladius' brief notice between two texts of very different provenance, which were to prove very influential. ${ }^{16}$ The first of these concerns the dream of "one of the holy Fathers' about an angel who came down from heaven with a scroll written on both sides, and asked to whom it might be entrusted; after various suggestions have been made, it turns out that "no one can be entrusted with it apart from Ephrem." The next morning, the Father who had had the dream "heard people saying 'Ephrem teaches as if a fountain was flowing from his

14 For Sozomen's chauvinistic reasons for this portrayal, see my "Syriac and Greek hymnography, problems of origins," Studia Patristica 16 $=($ Texte und Untersuchungen 129; 1985) $77-81$, repr. in Studies in Syriac Christianity (Aldershot, 1992), ch. VI.

15 Theodoret, Ecclesiastical History, IV.29. No hint of Ephrem's role there is given in Theodoret's chapter on Jacob of Nisibis in his Historia Philothea.

${ }^{16} \mathrm{Ed}$. R. Draguet, Les formes syriaques de la matière de l'histoire lausiaque, II (CSCO 398-9, Scr. Syri 173-4; 1978) 289-89 (text), 190-92 (tr.); an English translation is given in St. Ephrem the Syrian: Hymns on Paradise, $13-5$. 
mouth"." The second addition describes "a dream or a vision" which Ephrem saw in his youth, in which a vine sprung up from his tongue and bore abundant fruit: "the more the birds of the sky ate, the more the bunches of grapes multiplied and grew." These two additions also turn out to be translations from Greek, for they are taken from the alphabetical series of the Apophthegmata of the Fathers, ${ }^{17}$ and it is through the Syriac translation of Palladius (incorporated into the popular seventh-century collection of Egyptian monastic texts put together by 'Enanisho' under the title "The Paradise of the Fathers" ${ }^{18}$ ) that these two apophthegmata entered Syriac tradition, where they proved very popular and have influenced, among other things, the modern oriental iconographical tradition. ${ }^{19}$

Perhaps roughly contemporary with the Syriac translation of Palladius is Jacob of Serugh's memrā on Ephrem. ${ }^{20}$ Here and there Jacob uses phraseology that may reflect some of the Greek sources mentioned earlier/above: thus Ephrem is "a divine philosopher" (\$26), and "an amazing rhetor who vanquished the Greeks in his speech" (\$32), both perhaps reminiscences of Sozomen's account of Ephrem; a possible reflection of the first of the apophthegmata in the Syriac Palladius is to be found when Jacob says that Ephrem "caused a sweet fountain of blessed water to flow in our land" (\$23). But otherwise Jacob offers us a very different (and probably

17 Ephrem 2 and 1, in Patrologia Graeca 65, 168.

18 Book I, ch. 56, in E.A.W. Budge (ed.), The Book of Paradise (London, 1904) I, 277-9 (tr.), and II, 224-6 (text), and P. Bedjan (ed.), Acta Martyrum et Sanctorum, VII (Paris/Leipzig, 1897) 175-8. The alphabetical series does not feature as such in Syriac translation.

19 The vine episode is especially favoured; it features, for example, in an icon of St. Ephrem painted by Rabban Sheme un Can, of the Monastery of St. Mark, Jerusalem (illustrated in R. Derieva, The Meaning of Mystery: Icons of the Holy Land (Jerusalem, 1998), 61; I am most grateful to Rabban Shem'un Can for a postcard of his icon and a copy of R. Derieva's book). The text (on a scroll which Ephrem holds) is in the first person and would seem to be derived from the Testament (whose opening features on another scroll in the icon); the text, however, has many variations from Beck's edition (see note 21), some of which concur with the Vatican recension of the Life.

${ }^{20}$ Ed. J. Amar, "A Metrical Homily on Holy Mar Ephrem by Mar Jacob of Serugh," Patrologia Orientalis 47:1 (1995); cited here by Amar's numbering (of the couplets). 
much more accurate) impression of the man, concentrating on two specific aspects, his instruction of women and his innovative use of them in choirs; and his role as "teacher of truth" (\$29), combating heresies:

The blessed Ephrem saw that the women were silent from praise,

so in his wisdom he decided it was right that they should sing out.

Just as Moses gave timbrels to the young girls, so too the discerning man composed hymns for virgins.

As he stood among the sisters, it was his delight to stir these chaste women into songs of praise..

(\$S $96-8)$.

Of uncertain date are a whole number of texts written in the first person which claim to be by Ephrem himself, none of which, however, is likely to be genuine. Best known amongst these is the Testament of Ephrem, which is certainly a local Edessene product, and perhaps belongs to the early sixth century. ${ }^{21}$ Outtier has plausibly suggested ${ }^{22}$ that the author took as his clue a passage in C.Nis. 19:15 where Ephrem mentions that the first three bishops of Nisibis did not leave testaments. Elements from this product of the imagination are used in the Life (this is particularly clear in the Vatican recension of the Life in chapter 15, on the dream of the vine). ${ }^{23}$

It is elements of all of these texts (and other ones besides them, some now lost) that were brought together sometime in the latter half of the sixth century to form the Life of Ephrem. Perhaps

21 Ed. E. Beck, Des heiligen Ephraem des Syrers Sermones IV (CSCO 334-5, Scr. Syri 148-9; 1973) 43-69 (text), 53-80 (tr.).

22 Outtier, "Saint Ephrem d'après ses biographies," 24.

${ }^{23} \mathrm{P}$ and $\mathrm{V}$ specifically refer to the Testament, but, whereas P's text is largely based on the Syriac translation of Palladius, with only minor influence from the Testament (notably the added adjective, "when he was a small boy," and the statement that the vine "reached heaven"), $\mathrm{V}$ introduces further phraseology manifestly taken from the Testament, e.g. "(when he was a small boy) lying on his mother's lap." L, which places this vision at the end, does not mention the Testament, and derives its text word for word from the Syriac translation of Palladius. The Armenian has the episode in the same place as $\mathrm{P}$ V, while the Georgian has it in both positions $(\$ \$ 15,45)$. 
one should not be too surprised that in this Life, written some two hundred years after the time of its hero, a considerable distortion in the portrayal has taken place. Among the several elements that we meet with here for the first time the one of particular relevance for the second half of this paper concerns Ephrem's origins. Against the evidence of Ephrem's own hymns, where he states that he was brought up in the way of truth (H.c.Haer. 26:10; H. de Virg. 37:10), the Life depicts his parents as pagans, and his father as a priest of an idol, Abnil. ${ }^{24}$ Conceivably it was an adjacent passage in the first of these hymns that provided the author of the Life with his starting point in this mythopoeic development: Ephrem's own words read "I was born in the path of truth, / even though my childhood was unaware; but once I grew aware I acquired it in the furnace"-referring probably to baptism, which is not infrequently described in Syriac sources as a "furnace."

\section{THE LITURGICAL Tradition}

In the second part of my paper I turn to the liturgical tradition. Ideally one should go back to the rich manuscript tradition, but for reasons of practicality I have confined myself to the printed editions that are available. ${ }^{25}$

The Church of the East commemorates St. Ephrem, along with other Syriac teachers, on Friday of the fifth week after Epiphany. ${ }^{26}$ The printed Hudra offers little that is very specific: Ephrem (along with Narsai) is singled out as a teacher who "interpreted and illuminated the Scripture," and who "quenched

${ }^{24}$ Life, $\$ 1$; on the identity of the deity (Apollo, on the basis of the Georgian translation of the Life), see J. Tubach, "Der von Ephraem Syrus' Vater verehrte Gott. Apoll in Nisibis," in M. Tamcke, W. Schwaigert and E. Schlarb (eds.), Syrisches Christentum Weltweit: Studien zur syrischen Kirchengeschichte. Festschrift W. Hage (Münster, 1995) 164-79.

25 I use the following: (East Syriac) T. Darmo (ed.), Hudrā, I-III (Trichur, 1960-2) [= H]; P. Bedjan (ed.), Breviarium iuxta ritum Syrorum Orientalium id east Chaldaeorum, I-III (repr. Rome, 1938) [= BC]; (West Syriac) Clemens Joseph David (ed.), Breviarium iuxta ritum Ecclesiae

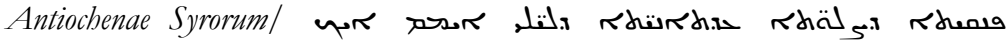

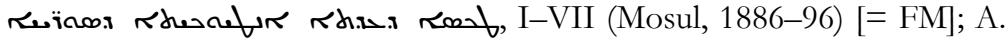

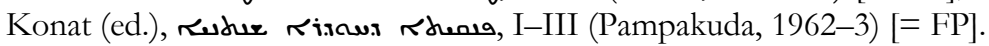

${ }^{26} \mathrm{H} \mathrm{I}, 761-79=$ BC I, 492-507. 
and rendered ineffective the sects of the erroneous heretics;" 27 Ephrem is compared to "a skilled doctor who blended the insights of the Scriptures for the healing of the sick world's ills," 28 and (in phraseology which possibly reflects that of Jacob of Serugh, \$23) Ephrem "became a fountain and caused life to flow for the whole world." 29 It is evidently from the Hudra that "Abdisho derived the title of "prophet" for Ephrem. ${ }^{30}$

[11] The printed editions of the West Syrian Fenqitho provide considerably more material of interest. The Syrian Catholic edition printed in Mosul commemorates St. Ephrem on three occasions: 28 th January, ${ }^{31} 19$ th February (together with St. Isaac the Teacher, of Edessa), ${ }^{32}$ and on Saturday of the first week of Lent (together with St. Theodore). ${ }^{33}$ This last commemoration has by far the most text, and is the only one to feature in the Syrian Orthodox edition of the Fenqitho printed in Pampakuda (Kerala); the texts, however, only partly coincide. ${ }^{34}$

One of the first things that strikes the reader of these liturgical texts of the Syrian Orthodox tradition is the considerable use that is made of Jacob of Serugh's memrā on Ephrem. This may be either direct quotation, or in a rephrased prose form. The direct

${ }^{27} \mathrm{H} \mathrm{I}, 766=\mathrm{BC} \mathrm{I}, 496$.

${ }^{28} \mathrm{H} \mathrm{I}, 767=\mathrm{BC} \mathrm{I}, 497$.

${ }^{29} \mathrm{H} \mathrm{I}, 768$ (cp. FP II, 67). In the corresponding passage in BC I, 498 Ambrose's name is substituted for that of Ephrem (in $\mathrm{BC}$ the commemoration is of the Syriac and Latin Fathers)!

${ }^{30} \mathrm{H} \mathrm{I}, 775$. The corresponding passage in BC I, 503 omits the word "prophet." "Abdisho, Catalogue, in J.S. Assemani, Bibliotheca Orientalis, III.1 (1725), 61.

${ }^{31}$ FM III, 393-6.

32 FM III, 447-50.

33 FM IV, 176-99. For the various dates on which St. Ephrem is commemorated in the Calendars, see F. Nau, Martyrologes et Ménologes orientaux (Patrologia Orientalis 10; 1915) 140 (index).

${ }^{34} \mathrm{FP}$ II, 54-72. Overlap between the two editions is to be found on the following pages:

$\begin{array}{lll}\text { FM IV 180 } & = & \text { FP II 56, 68 } \\ 181 & = & 56,65 \\ 188-9 & = & 57 \\ 190 & = & 59 \\ 191 & = & 62 \\ 195-6 & = & 70 .\end{array}$


quotations are quite long, and comprise couplets $21-9^{35}$ and 148 $62^{36}$ of Amar's recent edition of the memrä. These include a couplet which specifically refers to Ephrem's role in the instruction of women (\$152). Further material manifestly derived from the memra is to be found above all in the Sedro that features in the commemorations for 28th January and the Saturday of the first week of Lent. ${ }^{37}$ This may be illustrated from the following excerpt from the Sedro, where phraseology derived from the memra is italicised and the relevant couplet indicated $(\sim$ indicates approximate and-indicates omitted):

$\left(\sim \int \llbracket 5,9\right) \quad O$ diligent merchant $[\llbracket 9$ a] who brought (back) his talent 10,000 times over [\$5a], and it was not snatched away on the highways [ 99 a] of the evil world by the bandits of sin;

$(\sim$ 24) O new wine, whose fragrance and colour is from Golgotha, by drinking from which men and women became inebriated and gave praise to God with a loud voice;

$(\sim \$ 25) \quad$ O fountain, from whom burst forth all kinds of sounds that were passed on in the world and with his songs he aroused the entire earth to ponder on (God);

$(\sim$ 26) O divine philosopher who, by action, tanght his disciples in accordance with the Saviour's command;

$(\sim \$ 31) \quad O$ astute man who uttered all his teaching in simplicity in order to assist the simple, and who was able to be both serpent and dove, as he was commanded;

$(\sim$ \$32) O wondrous rhetor, who vanquished by his converse all the Greeks who were trained in rhetoric, in that, within a single word he was able to comprise many matters;

$(\sim \$ 46)$ He who gazed diligently in his mind on the great Moses, and after the model of the Hebrew women he taught the Aramaean women to give praise with their madräshe;

$(\sim \$ 157)$ He who measured out in orderly fashion and composed all his memre, ordering his teaching in metrical form, which he set out in the world;

$(\sim \$ 152)$ He who took women down to the contest of teaching, and with

\footnotetext{
${ }^{35}$ FM IV, 181; FP II 56 (\$\$24-26), 65 (\$28).

${ }^{36}$ FM IV, 196; FP II, 70 (\$\$148-52, 158-62).

${ }^{37}$ FM IV, 178.
} 
young girls was resplendent in battle against the doctrines of vanity;

$(-) \quad$ He whose memre and madrāshe are like the floods of the ocean, and of all the orators in the world none could feel out their depth or breadth;

$(-) \quad$ He who added glory to the Exalted One who has no need of praise, and now creation thunders with the sacred sounds of his teaching;

$(\sim \$ 155)$ He who became a crown for the people of the Aramaeans, (and) by him we have been brought close to spiritual beauty;

$(-) \quad$ He who raised up the horn of the Syrians everywhere, (and) from him henceforth we have learnt to sing to the Lord with sweet songs; ...

Not surprisingly, the influence of the Life is reflected in several passages, such as the statement that Ephrem was converted from paganism: thus God "caused Ephrem to pass from paganism and brought him to true faith;" 38 elsewhere it is specified that it was Jacob of Nisibis who converted him. ${ }^{39}$ As one might expect, the apophthegmata concerning the scroll and the vine (Life, $\$ \$ 14,15)$ also feature, the former indirectly, when Ephrem's experience of divine inspiration is compared to Ezekiel's consuming of a scroll (Ezek. 3:1-3). ${ }^{40} \mathrm{~A}$ number of passages refer to Ephrem's ascetic life on the mountains of Edessa (based on $\$ 13$ of the Life); one of these ${ }^{41}$ speaks of "the fragrance of (Ephrem's) life of mourning" (Rhalers x rui), employing a phrase derived from the Life of Abraham of Qidun, ${ }^{42}$ which was from an early date erroneously attributed to Ephrem.

38 Thus FM IV, 180, where Ephrem is being compared to Abraham who was told, "Go forth from your land and come to the land I will show you, the land of promise." Cp. also III, 393; IV, 178, 193; FP II, 68.

${ }^{39}$ FM III, 448.

${ }^{40}$ FM IV, 188; FP II, 57.

${ }^{41}$ FM III, 449. The "mountain of Edessa" also features in IV, 193 (where 30 years is specified as the length of time spent there; this is due to contamination with the Life of Jacob of Nisibis).

${ }^{42}$ Ch. 21, ed. Lamy, Sancti Ephraem Syri, IV, 63, = ed. Bedjan, Acta Martyrum et Sanctorum, VI, 490. 
A madräshà specifically on Ephrem states that Ephrem was sent to Edessa in order to counter the heresies of "the crazy Mani, the mad dog Marcion, and the errant Armianos (= Harmonios), son of Bardaisan." 43 The mention of Harmonios derives ultimately from Sozomen, but almost certainly reached the author of the madrasha through the Life, the Paris recension of which uses the passage from Sozomen in \$31. Although the "crazy Mani" (ultimately of Greek origin) and the "mad dog Marcion" do not feature in either the Paris or Vatican manuscripts of the Life, they are to be found in the longer form of $\$ 32$ which is to be found in the Armenian translation of the Life, and are based ultimately on Ephrem's madräshe against the Heresies (56:9). We know from an unpublished manuscript of the Life in Damascus, ${ }^{44}$ and from a fragment from among the New Finds in St. Catherine's Monastery, ${ }^{45}$ that chapters $31-2$ of the Life were originally in a form rather fuller than what is available in the two printed recensions (Paris, Vatican). The reference to Bardaisan's 150 psalms ${ }^{46}$ is likely also to derive from the Life (\$31, Paris recension), rather than directly from Ephrem, H.c.Haer. 53:6 (which the Life indirectly quotes).

Also from the Life are a few references to the meeting with Basil, ${ }^{47}$ and to the woman whose sins were forgiven. ${ }^{48}$

${ }^{43}$ FM IV, 190; FP II, 59. In FM "son of" has been lost, so that "the wicked Bardaisan" simply stands in apposition to Armonios/Harmonios.

44 See note 3, above.

45 See my Catalogue of Syriac Fragments (New Finds) in the Library of the Monastery of Saint Catherine, Mount Sinai (Athens, 1995), 52-54, and photographs of all the fragments on pp. 252-54.

46 FM IV, 190.

${ }^{47}$ FM IV, 194, 195, 196; FP II, 70. For the meeting of Basil and Ephrem, see O. Rousseau, "La rencontre de saint Ephrem et de saint Basile,” L'Orient Syrien 2 (1957): 261-84; 3 (1958): 73-90. The episode will have taken its origin in Basil's reference (Homily II.6 on the Hexaemeron) to a learned Syrian, whom later tradition (including Severus wrongly identified as Ephrem (criticized already by Moshe bar Kepha, Comm. on Hexaemeron, II.4; in fact it will have been Eusebius of Emesa: see L. van Rompay, "L'informateur syrien de Basile de Caesarée. A propos de Genèse 1,2," Orientalia Christiana Periodica 58 (1992): 245-51). A study of the precise relationship between Ps. Amphilochius, Life of Basil and the Syriac Life of Ephrem will have to await a critical edition of the former.

${ }^{48}$ Life, §39; FM IV, 195. 
In the course of the Sedro quoted above which made considerable use of Jacob's memrä, there is a further passage which is of some interest, sandwiched between a reference to Ephrem's teaching of women (based on Jacob) and a reference to his following in the footsteps of Basil (probably based on the Life): ${ }^{49}$

...He who in proper and chaste fashion introduced virgins into the schools of his teaching;

He who cunningly overcame the audacious sister of the accursed Bardaisan;

He who kept vigil, standing in fasting and prayer, day and night;

He who skilfully travelled in the footsteps of the great Basil; ...

The intriguing-and of course wildly anachronistic-allusion to Bardaisan's sister can fortunately be clarified by reference to chapter 54 of the Chronicle of Seert, ${ }^{50}$ which is devoted to Ephrem. For the most part this chapter is based on the Life, but at the end we encounter the following narrative:

It is told in certain histories that Bardaisan had composed a Gospel that differed from what Christ our Lord had said in the sacred Scripture. By means of it, he misled anyone who was feeble in faith and wandering in mind. Thus he corrupted the hearts of a multitude (of people) who looked into it. Now when Bardaisan died and God relieved the Church of him and his iniquity, Mar Ephrem craftily asked his sister to let him have the book so that he could have a look at it, after which he would return it to her. Now Satan, who loves corruption, incited her to ask him to have sexual intercourse with her, (Satan's) purpose being to disgrace him. Accordingly she asked him, and he replied, "Give me the book to look at, then I will get on with what you asked me, and sleep and have intercourse with you." She said, "Swear by Christ that you will do this, and that you will return the book to me once you have looked at it." He swore to her by

${ }^{49}$ FM IV, 194; III, 396.

${ }^{50}$ Ed. A. Scher (Patrologia Orientalis 5; 1910) 298. An earlier chapter, 26 (= Patrologia Orientalis 4 (1908) 293-5) is also devoted to Ephrem; this is often close to L, and like L, claims to be based on information from Ephrem's disciple Shem ${ }^{\circ}$ on of Samosata. 
Christ that he would do that if she consented (to her part of the bargain). She agreed, and handed over the book to him. Once he had received it from her, he got hold of a large amount of glue and spread it over all the pages. He then closed (the book) very tightly until it was all stuck together. He returned it to her, took his cloak and set off with her. When he arrived in the midst of the market, crowded with people, he spread out his cloak on the ground and said, "Here you are, get on with what you asked for: lie down here so that I can keep my promise." To which she replied, "Heavens above! Is there anyone in the world who would have intercourse with his wife in such a place, let alone with a strange woman?" He then said to her, "Since you cannot do this, then I have carried out my part of the agreement, and am clear of my oath, seeing that it was you who have refused." And so she went off-and the Most High God thwarted Satan of his hopes.

This anecdote has an interesting literary ancestry, for it is based on the third of the three apophthegmata concerning Ephrem in the Alphabetical Series of Apophthegmata. ${ }^{51}$ There it is a prostitute who approaches Ephrem, seeking either to seduce him, or, failing that, to cause him vexation. Curiously, this seems to be the only place in the later legends about Ephrem where this third apophthegma is used, in contrast to the first two, whose use is widespread. The motif of gluing together the pages of a heretical book is absent from the apophthegma, but turns up in the Greek Homily on Ephrem falsely attributed to Gregory of Nyssa: ${ }^{52}$ there it is again a woman from whom Ephrem borrows heretical works, but the theme of a sexual advance is absent; furthermore, it is not Bardaisan's "gospel" that Ephrem borrows, but two books by Apollinarius. Although there does not seem to be any evidence that Pseudo-Gregory's Homily on Ephrem was ever translated into Syriac, the episode, linked to Apollinarius, is nonetheless known to

51 Patrologia Graeca 65, 168.

52 Patrologia Graeca 46, 840BC (CPG 3193); Outtier, "Saint Ephrem d'après ses biographies," 27 , dates it to "vers le VII' siècle" (in the table on p. 17 he gives 650$)$. 
and used by the compiler of a Maronite synaxarion in his entry on Ephrem (28th January), recently published by Amar. ${ }^{53}$

Evidently what we have in the Chronicle of Seert is the combination of two originally separate floating motifs, the sexual proposition made to Ephrem (derived from the third apophthegma under Ephrem's name), and the gluing together of the pages of a heretical book - a motif which is used independently and in a different context by Pseudo-Gregory. The sexual proposition by Bardaisan's sister in the Chronicle of Seert is but one, though the most risqué, of a number of anecdotes about loose women and Ephrem (who always comes out well) which are to be found in the later biographical tradition. One may suppose that they took their origin in circles which sought to emphasize Ephrem's unshakable chastity, and to nip in the bud any possible suggestion on the part of hostile parties that Ephrem's association with the teaching of women was in the slightest way improper.

A further probable allusion to the episode with Bardaisan's sister, found elsewhere in the Fenqitho, gives rise to a comparison with the biblical Joseph: ${ }^{54}$

God gave success and advancement to the chaste and upright Joseph, the resplendent, thus putting to shame the insolence of the Evil One who sought to impose upon him a blemish; (God) again gave success and a crown to the holy Mar Ephrem, at the hands of the crazed woman, and thus the high rank of his purity grew.

Biblical parallels of a typological nature, such as this, are in fact characteristic of the liturgical tradition, and we find further comparisons with Abraham, ${ }^{55}$ Moses, ${ }^{56}$ Samuel, ${ }^{57}$ Jeremiah $^{58}$ and Ezekiel. ${ }^{59}$

53 J. Amar, "An unpublished Karšuni Arabic Life of Ephrem," Le Muséon 106 (1993): 119-44.

${ }^{54}$ FM IV, 180; FP II, 56.

${ }^{55}$ See above, note 38. A much more extended list of biblical models imitated by Ephrem is to be found in Ps. Gregory of Nyssa, Patrologia Graeca 46, 844-5 (Abel, Enoch, Noah, Abraham, Isaac, Jacob, Joseph, Moses, Joshua, Samuel, Elijah, Elisha, Paul).

56 FM IV, 180, where Ephrem being led to Jacob is compared to Moses as herdsman of Jethro.

${ }^{57}$ FP II, 59. 
Two different passages in the Fenqitho introduce a word play on Ephrem's name, comparing him with the Euphrates: ${ }^{60}$

O Sea of wisdom and Profundity of symbols, Ephrem, the Euphrates who fructified with his teaching the living waters of souls (... Rमت्ars riv);

and: ${ }^{61}$

He who became the mighty Euphrates with his teaching in the City of God, which is the holy Church.

It so happens that the same word play also features in the later Greek tradition, in Pseudo-Gregory of Nyssa's Panegyric on Ephrem. ${ }^{62}$

[22] Finally, it may be noted that the Mosul edition of the Fenqitho contains one of the supposedly autobiographical texts attributed to Ephrem, a soghitha beginning "How often have I hungered..." 63

Sufficient has been said to indicate that the West Syriac liturgical tradition, at least in so far as it is represented in the printed editions of the Fenqitho, draws on a variety of different sources, prominent among which are Jacob of Serugh's memrä on Ephrem and the Life. The result, not surprisingly, is that no consistent portrait is offered of the saint who is being commemorated.

${ }^{58}$ FM IV, 188; FP II, 59.

${ }^{59}$ See above, note 38 .

${ }^{60}$ FM IV, 186.

61 FP II, 71.

${ }^{62}$ Patrologia Graeca 46, 824A.

${ }^{63}$ FM IV, 191-2. The soghitha was also published by I.E. Rahmani, Studia Syriaca I (Charfet, 1904) 12-3; it is certainly not genuine. Another soghitha attributed to Ephrem, present in Mingana syr. 190, ff. 126a-127b

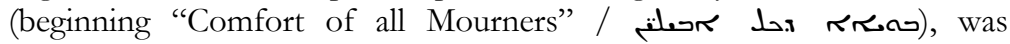
considered by Vööbus to be genuine: Literary Critical and Historical Studies, 16-8, and History of Asceticism, II, 73-4; this, however, cannot be the case since it includes the adjectival form sich is not otherwise attested before the sixth century. 


\section{CONCLUSION}

[24] Academics who deal with the past are frequently urged to make their subject relevant to the modern day, and maybe this is how we should view the transformations that have taken place in the Syriac tradition with the portrait of St. Ephrem: perhaps all that the fifthand sixth-century biographers wanted to do was to present the saint in a modern guise, to make him relevant to their own context. We, with our benefit of hindsight, can see that in the process of "updating" St. Ephrem, they have perverted the truth. But instead of simply condemning them, we should learn a lesson from what they have done, and beware of repeating their error, that is, of not allowing St. Ephrem's own writings speak for themselves. In other words, in order to gain a true picture of the saint, one needs to go back to the genuine texts themselves. This was still possible in the sixth century, when the Life of St. Ephrem was compiled, for manuscripts of his complete madräshe cycles still circulated then; as the centuries advanced, however, two processes took place simultaneously: on the one hand, only a small selection of madrashe continued to be copied, and usually this was in abbreviated form, incorporated into the medieval hymnaries, or Fenqyotho; ${ }^{64}$ and on the other hand, an ever increasing amount of anonymous material came to claim his authorship, thus conveying a very different impression about him. A phenomenon related to the first of these processes is the pillaging of Ephrem's genuine madräshe for isolated stanzas and then supplementing them by new ones of an essentially moralizing character which provide the genuine stanzas with a completely different setting. ${ }^{65}$

It has in fact only been within the last forty five odd years that it has once again become possible to go back to the real Ephrem, thanks above all to the late Dom Edmund Beck's editions of the surviving madräshe cycles. A glance at his introductions will indicate that it is largely sixth-century manuscripts that provide the basis for his editions. That such early manuscripts should have survived at

64 See my "The transmission of Ephrem's madrāshe in the Syriac liturgical tradition," in E.A. Livingstone (ed.), Studia Patristica 33 (1997) 490-505.

${ }^{65}$ An example is given in my "The transmission," 495-6. 
all is very largely due to the tenth-century bibliophile abbot Moses who, like St. Ephrem, originated in Nisibis. ${ }^{66}$

\section{APPENDIX I: \\ EXTERNAL ATTESTATION CONCERNING EPHREM}

Summary chronological chart to mid seventh century.

This table is simply intended as an aide memoire; it should be noted that many of the dates ascribed to pseudonymous works are very uncertain.

(373 Death of Ephrem).

c. 377 Epiphanius, Panarion 51,22,7 (Ephrem "the sage among the Syrians' on the date of the Nativity).

392 Jerome, de viris illustribus, 115 (knows a work by Ephrem on the Holy Spirit already translated into Greek).

c. 400 Anonymous, Life of Abraham of Qidun, J\$24, 28 (ed. Lamy, IV, 69, 77; mention of Ephrem).

c. 420 Palladius, Lausiac History, 40.

c. 440 Sozomen, HE III.16.

c. 450 Theodoret, HE II.30 (siege of Nisibis); IV.29 (mostly from Sozomen). Letter 145 (PG 83, 1384D; mention of Ephrem as 'Lyre of the Holy Spirit').

482/4 Philoxenos (quotes from Ephrem's Hymn Cycles in the Florilegium at the end of his Discourses against Habib).

c. 500 Gennadius, de viris illustribus, 3 (Ephrem's disciple Paulonas), 67 (memrā on destruction of Nicomedia).

c. 500 Greek Apophthegmata (Ephrem and scroll; Ephrem and vine).

$500+$ Syriac translation of Palladius (incorporating Apophthegmata).

$500+$ Testament of Ephrem (utilising second apophthegma, by way of Syriac Palladius).

519 Earliest dated manuscript of Ephrem's madräshe (BL Add. 14571).

519 Severus, C. Grammaticum III.2 (ch. 39, ed. Lebon, 244 end;

66 On Moses of Nisibis, see J. Leroy, "Moise de Nisibe," in [I] Symposium Syriacum (Orientalia Christiana Analecta 197; 1974) 457-70, and M. Blanchard, "Moses of Nisibis (fl. 906-943) and the Library of Deir Suriani," in L.S.B. MacCoull (ed.), Studies in the Christian East in Memory of Mirrit Boulos Ghali (Publications of the Society for Coptic Archaeology, North America, 1; 1995) 13-24. 
identifies Basil's “Syrian' as Ephrem “because he certainly will have met him during his lifetime').

pre Jacob of Serugh, Memra on Ephrem.

521

c. 550 Chronicle of Edessa (records death of Ephrem on 9 June 373).

?6th Ps. Amphilochius, Life of Basil (meeting of Ephrem and Basil).

cent.

6th Syriac Life of Ephrem (surviving in several recensions).

cent. +

c. 600 Barhadbeshabba, Ecclesiastical History (PO 23, 33; Ephrem's nephew Abshlama, bishop of Edessa, at Council of Nicaea). [Another(?) nephew of Ephrem, Absimya, is said to have written a poem on the incursion of the Huns: Chron. 846, in Chronica Minora II.208; Michael Syrus, Chronicle, VIII.1 (end)].

c. 600 Barhadbeshabba, Cause of Schools (PO 4, 377, 381; Ephrem made "Exegete" at Nisibis by Jacob; founds school in Edessa).

c. 650 Ps. Gregory of Nyssa, Encomium on Ephrem.

\section{APPENDIX II: THE SyRIAC LIFE OF EPHREM}

(For abbreviations, see note 3 . The sequence of chapters is that of $\mathrm{P}$ )

\begin{tabular}{|c|c|c|c|c|}
\hline & $\mathrm{P}$ & $\mathrm{V}$ & $\mathrm{L}$ & $\begin{array}{l}\text { Ultimate source } \\
\text { (or inspiration) }\end{array}$ \\
\hline Origins & 1 & 1 & $=$ & \\
\hline Expelled by father & 2 & 2 & $=$ & \\
\hline Meeting with Bp. Jacob & 3 & 3 & & (Ephrem, C.Nisibena) \\
\hline E's supposed child & 4 & 4 & & $\begin{array}{l}\text { (See P. Canart, Anal. Boll. } \\
84 \text { (1966), 309-33) }\end{array}$ \\
\hline Council of Nicaea & 5 & 5 & & cp. Theodoret, HE I.7 \\
\hline Siege of Nisibis & 6 & 6 & & $\begin{array}{l}\text { Theodoret, HE II.32; } \\
\text { (Ephrem, C.Nisibena 1) }\end{array}$ \\
\hline Death of Jacob & 7 & 7 & & \\
\hline Constans and Julian & 8 & 8 & & \\
\hline E leaves Nisibis & 9 & 9 & $=$ & \\
\hline Arrives at Edessa & 10 & 10 & $=$ & \\
\hline Encounter with woman & 11 & 11 & & Sozomen, HE III.16 \\
\hline Works in bath house & 12 & 12 & $=$ & \\
\hline
\end{tabular}




\begin{tabular}{|c|c|c|c|c|}
\hline Joins monks on mountain & 13 & 13 & $=$ & \\
\hline Vision of tomos & 14 & 14 & $=$ & $\begin{array}{l}\text { Apophthegmata }> \\
\text { Palladius (Syr) }\end{array}$ \\
\hline Vision as a child & 15 & 15 a & t end & $\begin{array}{l}\text { Apophthegmata }> \\
\text { Palladius (Syr) and } \\
\text { Testament }\end{array}$ \\
\hline Comm. on Pentateuch & 16 & 16 & & (Ephrem, Comm. Genesis) \\
\hline $\begin{array}{l}\text { Flees from fame, } \\
\text { meets angel }\end{array}$ & 17 & 17 & & \\
\hline $\begin{array}{l}\text { Stoned by heretics } \\
\text { and pagans }\end{array}$ & 18 & 18 & $=$ & \\
\hline Writings against heretics & 19 & 19 & & (Ephrem, H.c Haereses) \\
\hline Pupils & 19 & 20 & & Sozomen, Testament \\
\hline $\begin{array}{l}\text { Desires to see Basil } \\
\text { (pillar of fire) }\end{array}$ & 20 & 21 & & Ps.Amphilochius \\
\hline Storm at sea & 21 & 22 & $=$ & \\
\hline Arrival in Egypt & 22 & 23 & $=$ & \\
\hline Meeting with Bishoi & & 24 & & \\
\hline Diet and appearance & 23 & 24 & $=$ & \\
\hline $\begin{array}{l}8 \text { years in Egypt; } \\
\text { refutes Arians }\end{array}$ & 24 & 24 & $=$ & \\
\hline Sails to Caesarea & 25 & 25 & $=$ & \\
\hline Meeting with Basil & 25 & 25 & $=$ & Ps.Amphilochius \\
\hline Ordained deacon by Basil & & $26-$ & $=$ & Ps.Amphilochius \\
\hline Wording of doxology & 26 & 29 & & Basil, On Holy Spirit \\
\hline Basil and Gen. 1:2 & 27 & 30 & $=$ & $\begin{array}{l}\text { Basil, Hom. on } \\
\text { Hexaemeron; cp. Sozomen }\end{array}$ \\
\hline E returns & 28 & (29) & & \\
\hline Episode at Samosata & 29 & 31 & $=$ & \\
\hline $\begin{array}{l}\text { Return to Edessa, } \\
\text { deals with heretics }\end{array}$ & 30 & 32 & $=$ & (Ephrem, H.c Haereses) \\
\hline $\begin{array}{l}\text { Writes hymns to rival } \\
\text { Harmonius }\end{array}$ & 31 & (33) & & Sozomen \\
\hline $\begin{array}{l}\text { Writes against "Seven" } \\
\text { of Bardaisan }\end{array}$ & 32 & 33 & & $\begin{array}{l}\text { (Ephrem, Prose } \\
\text { Refutations) }\end{array}$ \\
\hline Heals paralytic & 33 & 34 & $=$ & \\
\hline
\end{tabular}




\begin{tabular}{|c|c|c|c|c|}
\hline $\begin{array}{l}\text { Basil's attempt to ordain } \\
\text { E bishop }\end{array}$ & 34 & 35 & $=$ & $\begin{array}{l}\text { cp. Sozomen; Ps. } \\
\text { Amphilochius }\end{array}$ \\
\hline E's friends and writings & 35 & 36 & & \\
\hline Invasion of Huns & 36 & & & $\begin{array}{l}\text { (Chron. Edessa, Sel. } 706= \\
\text { AD 395) }\end{array}$ \\
\hline $\begin{array}{l}\text { Valens' intended } \\
\text { persecution }\end{array}$ & 37 & & & Socrates, HE IV.18 \\
\hline Poem on Edessa's rescue & 38 & 37 & & \\
\hline $\begin{array}{l}\text { Caesarean woman's sins } \\
\text { wiped out }\end{array}$ & 39 & 38 & & Ps. Amphilochius \\
\hline Death of Basil & 40 & 39 & & \\
\hline Famine at Edessa & 41 & 40 & $=$ & Palladius, Sozomen \\
\hline Death of Ephrem & 42 & 41 & $=$ & \\
\hline
\end{tabular}


